\title{
DEVELOPMENT OF ACCOUNTING JENGA AS A LEARNING MEDIA TO IMPROVE STUDENTS MOTIVATION
}

\section{PENGEMBANGAN JENGA AKUNTANSI SEBAGAI MEDIA PEMBELAJARAN UNTUK MENINGKATKAN MOTIVASI BELAJAR SISWA}

\author{
By: \\ Theresia Lindha Widya Sari \\ Accounting Education Study Program Yogyakarta State University \\ theresialindhaws@gmail.com \\ Mimin Nur Aisyah \\ Lecturer in Accounting Education Department Yogyakarta State University
}

\begin{abstract}
This research aimed at: (1) developing Accounting Jenga as a learning media in Accounting Equation material for students in class XI IPS 1 SMA Negeri 1 Prambanan Klaten, (2) measure the feasibility of Accounting Jenga based on the assessment of material expert, media expert, subject practitioner, students' responses, and (3) measure students' motivation improvement. This research was Research and Development (R\&D) adapting the ADDIE model. Data were collected through questionnaires distribution and were analysed using qualitative quantitative method. The results were: (1) average score obtained from Material Expert was 4.83 classified as Strongly Feasible, (2) average score obtained from Media Expert was 4.27 classified as Strongly Feasible, and (3) average score obtained from Subject Practitioner was 4.93 classified as Strongly Feasible. Based on students' responses, average score obtained in small group tryout was 4.51 classified as Strongly Feasible and average score obtained in field tryout was 4.26 classified as Strongly Feasible. Students' motivation improved $6.62 \%$ from $73.02 \%$ to $79.32 \%$. Paired sample $t$ test result showed that the improvement is significant ( $\operatorname{sig} 0.000$ and $\mathrm{t}_{\text {value }}$ 5.287).
\end{abstract}

Keywords: Accounting Jenga, Learning Media, Learning Motivation, Accounting Equation, ADDIE.

\begin{abstract}
Abstrak
Penelitian ini bertujuan untuk: (1) mengembangkan Jenga Akuntansi sebagai media pembelajaran pada materi Persamaan Dasar Akuntansi untuk siswa kelas XI IPS 1 SMA Negeri 1 Prambanan Klaten, (2) mengukur kelayakan Jenga Akuntansi berdasarkan penilaian ahli materi, ahli media, praktisi pembelajaran, respon siswa, dan (3) mengukur peningkatan motivasi belajar siswa. Penelitian ini merupakan penelitian dan pengembangan dengan mengadaptasi model ADDIE. Teknik pengumpulan data menggunakan kuesioner yang dianalisis dengan metode deskriptif kualitatif dan kuantitatif. Hasil penelitian adalah: (1) perolehan skor rata-rata dari Ahli Materi adalah 4,83 dengan klasifikasi Sangat Layak, (2) perolehan skor rata-rata dari Ahli Media adalah 4,27 dengan klasifikasi Sangat Layak, (3) perolehan skor rata-rata dari Praktisi Pembelajaran adalah 4.93 dengan klasifikasi Sangat Layak. Berdasarkan respon siswa, perolehan skor rata-rata dari uji coba kelompok kecil adalah 4,51 dengan klasifikasi Sangat Layak dan perolehan skor rata-rata dari uji coba lapangan adalah 4,26 dengan klasifikasi Sangat Layak. Motivasi siswa meningkat sebesar 6,62\% dari 73,02\% menjadi 79,32\%. Hasil perhitungan paired sample t test menunjukkan bahwa peningkatan tersebut signifikan (sig 0,000 dengan $t_{\text {hitung }}$ 5,287).
\end{abstract}

Kata Kunci: Jenga Akuntansi, Media Pembelajaran, Motivasi Belajar, Persamaan Dasar Akuntansi, ADDIE. 


\section{INTRODUCTION}

Education is an effort for preparing students to deal with the environment that changes rapidly (Tim Dosen UPI, 2012: 12). According to Driyarkara in Siswoyo (2013: 1), education is a symptom of universe and takes a lifetime of human beings. Education becomes important in life. People can not do a lot of things, do their creativities, and be an intelligent, independent, and insightful person if they do not have education. Education that is taken by students in the school will be measured the success by the knowledge, skills, and good attitude of the individual in accordance with the expected goals.

Accounting is a branch of social science that becomes the main subject for students in Social Program. Accounting subject requires precision, accuracy, and patience in learning the material, so it is often considered as a difficult subject.

One of the Basic Competences in this subject is Accounting Equation. This learning material is the first basic that must be understood by students before they continue to learn the next learning material. But, not all of the students are able to understand this learning material well. This lack of students' ability caused by several factors, one of the factors is because the students are getting bored by the method or the way that teacher used. The teacher continuously uses the same method, so it becomes monotonous.

According to Barnadib in Siswoyo (2013: 116), a teacher is a person who intentionally influences students to achieve a higher level of humanity. In other words, teacher is the person who will act as a guide that shows the direction of the learning process will take place.

As an educator, a teacher should be able to go through the limits of themselves in order to become a creative teacher in delivering the learning materials. Teacher does not have to use the conventional method, such as teaching by using a book as the reference or write questions and exercises on the board to be copied by the students later. To make the learning material seem attractive, teacher should have much of variety learning methods that can make the students pay attention to the teacher without neglecting the learning objectives. If students already feel attracted to learning materials, teacher will not have any difficulties to explain the material. The main key to obtain the interest is to increase students' motivation.

Efforts to increase students' motivation can be done by using learning media. The use of learning media can assist teacher in delivering learning material. The learning media that is currently being developed is a game.

Game is the main support in playing activities. According to Hidayat (2013: 9), game is a recreational activity to have fun and be played at leisure. Game is usually played individually or in groups. Game comes in different types, concepts, and forms (Pinasthika, et al., 2014: 204). In educational scope, game is a friendly way for educators to help presenting the learning materials in an attractive way to students (Sugar, 2002: 4). Games can help teachers to maximise the learning potential of each student. In addition, game also can improve students' motivation to the high level (Sugar, 2002: 12).

Besides that, game is a significant force in the students' lives. Game will be more motivating, challenging, and attractive than a formal and conventional learning method like that is usually practiced in schools (Williamson, 2008).

There is a wide variety of games, one of the games is jenga. Jenga is a game that consists of 54 wooden blocks which is arranged in such a way to become a jenga tower. Jenga is suitable to be played by children ages eight years old to adult.

To be able to play jenga, it requires physical skills, brain skills, and mental skills. Physically, to play jenga needed a player's ability to take the blocks without making the jenga tower collapse. The ability 
to make a strategy, accuracy in determining which blocks that can be taken easily, and improve concentration, shows that the brain skills are required in playing jenga. While the mental skills required by the players to control their emotions in order to be able to play calmly and carefully, so it is not easy to make the jenga tower collapses.

These three skills are related to each other. However, the mental skill is the most dominant skill. Mental skill is the ability of a person to motivate themselves, endurance themselves to face failures, control the emotions, and also to control their soul well (Kholidiyah, 2013: 2). The good management of mental skills has a very important role. The emotions that can be controlled well can make a person manages their brain skills to think clearly in determining the strategy to play jenga and also make it easier to manage their physical skills.

Researcher is interested to develop jenga game into a learning media that can improve students' motivation. Jenga appropriates to be played by senior high school students because students' ages classified as teenagers, so they are suitable to play this game. In addition, jenga is appropriate to be used in accounting subject, especially in Accounting Equation material because this game involves three skills at once. So, it is effective to attract students' attention and able to make the students focus on the learning material. By having a high concentration, the learning material will be easier to understand.

Based on the observation in class XI

IPS 1 SMA Negeri 1 Prambanan Klaten, researcher found two kinds of problems in accounting learning process, especially in Accounting Equation material. The problems were the students' motivation was low and monotonous method that was used by the teacher. Students were easily bored so they tend to ignore when the teacher gave an explanation. Students also prefer to chat with friends or did the other subject assignment than to take a listen to the learning material that was ongoing. It showed that students had low motivation.

In addition, teacher always applied speech method in teaching. This teaching method was done by the teacher every time the learning process took place. Teacher only used a book as the reference of learning and never used any learning media. It made the students feel that Accounting Equation material was boring. If students already feel bored, the teacher will find difficulties to get students' attention. It will obstruct the learning process, whereas this material is very important to be understood by students because it is the basic of accounting subject itself.

From the results of observation made by the researcher, it can be concluded that the learning activities in class XI IPS 1 SMA Negeri 1 Prambanan Klaten requires a learning media that can improve the students' motivation. This learning media that can be used in Accounting Equation material is Accounting Jenga.

Based on the problems above, it is necessary to conduct research to develop a learning media in Accounting Equation material to improve students' motivation in class XI IPS 1 SMA Negeri 1 Prambanan Klaten. Thus, researcher interested to conduct a research entitled "Development of Accounting Jenga as a Learning Media to Improve Students Motivation in Class XI IPS 1 SMA Negeri 1 Prambanan Klaten Academic Year 2016/2017."

\section{RESEARCH METHOD}

\section{Type of Research}

This research was a Research and Development (R\&D). R\&D was an effort in developing a prototype of a tool (Ali, 2010: 117). This research method was used to produce a specific product and measure the effectiveness of the products (Sugiyono, 2012: 407).

\section{Place and Time of Research}

This research has been conducted in SMA Negeri 1 Prambanan Klaten that is 
located at Jalan Manisrenggo $\mathrm{Km} \mathrm{2,5}$ Prambanan, Klaten 57454. This research has been conducted from July to October 2016 which includes planning, researching, and reporting steps.

\section{Subjects of Research}

The subjects of this research were media expert, material expert, accounting subject practitioner, and students in class XI IPS SMA Negeri 1 Prambanan Klaten. The objects of this research were the feasibility of Accounting Jenga and the students' motivation.

\section{Procedure}

This research was adapting the ADDIE Model by Dick and Carry (1996) (Mulyatiningsih, 2011: 5). ADDIE first appeared in 1975 (Muruganantham, 2015: 52). It was created by the Centre for Educational Technology at Florida State University. The ADDIE model developed by Dick and Carry in 1978 and Russell Watson revised in 1981, and was considered essential in the development of educational and training programs.

ADDIE had function to be guidelines in creating a learning media that is effective, dynamic, and supporting learning activities. This model used five stages of development, namely: Analysis, Design, Development, Implementation, and Evaluation. The explanation of each stage is described as follows:

\section{a. Analysis}

Analyse was done to know the need of product in order to solve the learning problem. The activities in this stage were:

1) Analyse the objective and the targets of Accounting Jenga that is being developed.

2) Analyse Standard Competence and Basic Competence.

3) Analyse the indicators of Basic Competence which are included in Accounting Jenga. b. Design

There were three steps in design stage as follows:

1) Planning the product's design

Researcher began to design the initial product. The learning material that was delivered in Accounting Jenga was arranged based on the Basic Competence, i.e. Accounting Equation.

2) Arrange game instruction and the cards

Accounting Jenga took form like a jenga game in general. However, there were some differences in the rules of the game because Jenga Accounting must be adapted to its purpose as a learning media. Therefore, researcher needed to develop the rules that could lead the players to be able to use Accounting Jenga in learning activities.

3) Arrange the assessment instrument to evaluate the product

Researcher arranged the grating of assessment instruments, i.e. questionnaires. These questionnaires has been filled by material expert, media expert, subject practitioner, students in class XI IPS.

c. Development

The activities in this stage are:

1) Product making

In this stage, researcher began transforming the design of Accounting Jenga into a real product. Accounting Jenga was printed out in this stage. The Accounting Jenga consists of 54 pieces of wooden blocks with six colors, i.e. red, yellow, green, blue, black, and white, one dice with similar colors in the six sides, and also three sets of cards.

The cards were divided into Level 1, Level 2, and Level 3. It is 
done in order to make all of the learning materials in the Basic Competence Accounting Equation can be delivered well and deeper.

The cards in Accounting Jenga were Material Cards (red), Question Cards (yellow), Answer of the Question Cards (orange), Bonus Cards (white), Answer of Bonus Cards (pink), Opportunity Cards (green), Challenge Cards (blue and black), and Point Cards (purple).

2) Product validation by experts

In this stage, the initial product was validated by material expert, media expert, and accounting subject practitioner. The results of the validation form of suggestions, comments, and feedback is used as the basis for revising the developed product.

3) Product revision stage I

The product was revised based on suggestions, comments, and feedback which were given by material expert, media expert, and subject practitioner in the previous step.

d. Implementation

1) Small group tryout

In this step, Accounting Jenga was tried out in a small group. According to Dick \& Carry in Setyosari (2012: 225), small group tryout consisted of $6-8$ subjects. Accounting Jenga was tried out on eight students in class XI IPS 3.

After the students learn about Accounting Equation material by using Accounting Jenga, the questionnaires were given to the students. It was done to know their responses, get advices, and also suggestions as an evaluation to Accounting Jenga.

2) Product revision stage II

Product revision stage II was done based on the feedback and suggestions from students on small group tryout stage if it necessary. However, the advices and suggestions from the validators not be ignored to avoid the problems of the improvements that have been done before.

3) Field tryout

In this stage, the product was tried out to all of the students in class XI IPS 2 SMA Negeri 1 Prambanan Klaten during the learning activities. The field tryout has been held in two days. Researcher taught by using Accounting Jenga as a learning media.

Students learned by using Accounting Jenga Level 1 in the first meeting. While Level 2 and Level 3 were used in the second meeting. At the end of the lesson in day two, the questionnaires were given to the students to know their responses and advices to the Accounting Jenga as a learning media.

4) Product revision stage III

Product revision stage III was done if there was a need to revise the product after the field tryout. This revision based on the feedback and suggestions from students on field tryout stage. However, advices and suggestions from the validators not be ignored to avoid the problems of the improvements that have been done before.

e. Evaluation

In the final stage, researcher measured the achievement of the product's objectives. After passing the product validation and product tryout in the previous stage, then researcher obtained the final product in the form of Accounting Jenga that was ready to be used in learning activities. Then, it was implemented in class XI IPS 1 SMA 
Negeri 1 Prambanan Klaten to measure the improvement of students' learning motivation.

\section{Data, Research Instrument, and Data Collection Techniques}

a. Data

There are two types of data that were collected in this research, i.e. quantitative data and qualitative data.

1) Qualitative data was a data that takes form of criticism and suggestions to the learning media Accounting Jenga from material expert, media expert, and subject practitioner. The data represented the quality of Jenga Accounting.

2) Quantitative data was qualitative data which has been converted by following the conversion guidelines. The qualitative data obtained from the assessment of learning media by media expert, material expert, accounting subject practitioner, and the students' responses about the feasibility of Accounting Jenga.

This research used questionnaire to obtain data. Questionnaire was a technique of data collection that was done by providing a set of questions or a written statement to be answered by respondents (Sugiyono, 2012: 199). There are three kinds of questionnaires used, i.e. validation questionnaire, students' responses questionnaire, and students' motivation questionnaire.

Validation questionnaire was filled by the validator team that consisted of material expert, media expert, and accounting subject practitioner. Students' responses questionnaire was filled by students to know their feedback and suggestions about the Accounting Jenga. While students' motivation questionnaire used to measure the motivation improvement. Therefore, students' motivation questionnaire was made into two kinds, i.e. students' motivation before and after using Accounting Jenga

\section{b. Data Analysis Techniques}

The data has been analysed by using qualitative descriptive and quantitative descriptive method. Qualitative descriptive method used to process data that took form of comments and suggestions from material expert, media expert, subject practitioner, and students' responses. Quantitative descriptive analysis used to process the data obtained through questionnaires that took form of score. It was done to measure the feasibility of Accounting Jenga. The steps to analyse the feasibility of Accounting Jenga:

1) Changing the qualitative values to quantitative values by following this rules:

Table 1. Scoring Rules of Validation Questionnaires

\begin{tabular}{|l|c|}
\hline \multicolumn{1}{|c|}{ Classification } & Score \\
\hline Very Good & 5 \\
\hline Good & 4 \\
\hline Enough & 3 \\
\hline Bad & 2 \\
\hline Very Bad & 1 \\
\hline
\end{tabular}

Source: Widoyoko (2011: 93)

2) Calculating the value of the average score of each indicator with formula:

$$
\bar{X}=\frac{\sum X}{N}
$$

Description:

$$
\begin{array}{ll}
\bar{X} & =\text { average score } \\
\sum X & =\text { total score } \\
N & =\text { number or aspect item }
\end{array}
$$

(Sukardjo, 2005: 52)

3) Interpreting the number of qualitative value to every aspect by using a fivescale conversion formula as follows: 
Table 2. Score Conversion to Five-Scale

\begin{tabular}{|c|c|c|}
\hline Interval Score & Range & Category \\
\hline$X>\bar{X}+1.80 S B i$ & $X>4.20$ & $\begin{array}{l}\text { Strongly } \\
\text { Feasible }\end{array}$ \\
\hline $\begin{array}{l}\bar{X}+0.60 S D i<X \\
\leq \bar{X}+1.80 S D i\end{array}$ & $\begin{array}{c}3.40<X \leq \\
4.20\end{array}$ & Feasible \\
\hline $\begin{array}{l}\bar{X}-0.60 S D i<X \\
\leq \bar{X}+0.60 S D i\end{array}$ & $\begin{array}{c}2.60<X \leq \\
3.40\end{array}$ & Enough \\
\hline $\begin{array}{l}\bar{X}-1.80 S D i<X \\
\leq \bar{X}-0.60 S D i\end{array}$ & $\begin{array}{c}1.80<X \leq \\
2.60\end{array}$ & Unfeasible \\
\hline$X \leq \bar{X}-1.80 S B i$ & $X \leq 1.80$ & $\begin{array}{c}\text { Strongly } \\
\text { Unfeasible }\end{array}$ \\
\hline
\end{tabular}

Description:

$$
\begin{aligned}
\bar{X} & =\text { actual score } \\
\bar{X} i & =3 \\
S D i & =0.67
\end{aligned}
$$

Source: Sukardjo (2005: 53)

Besides that, this research also conducted to measure students' motivation improvement. Therefore, the students' motivation analysis was done by doing these steps:

1) Analysing the quantitative data from students' learning motivation questionnaire by scoring it based on the following conversion table:

Table 3. Score Criteria to Students' Learning Motivation

\begin{tabular}{|l|c|c|}
\hline \multirow{2}{*}{ Options } & \multicolumn{2}{c|}{ Score Item } \\
\cline { 2 - 3 } & Positive & Negative \\
\hline $\begin{array}{l}\text { Strongly } \\
\text { Agree }\end{array}$ & 4 & 1 \\
\hline Agree & 3 & 2 \\
\hline Disagree & 2 & 3 \\
\hline $\begin{array}{l}\text { Strongly } \\
\text { Disagree }\end{array}$ & 1 & 4 \\
\hline
\end{tabular}

2) Summing up the scores for each aspect of motivation.

3) Calculating the score of students' learning motivation for each aspect with formula:

$$
\begin{aligned}
& \text { \%learning motivation score } \\
& =\frac{\text { learning motivation score }}{\text { maximum score }} \times 100 \%
\end{aligned}
$$

4) Calculating the differences in average score motivation of each student before and after using Accounting Jenga with paired sample t-test.

Paired sample t-test was a t test which the sample was correlated each other. The $\mathrm{t}$ value was matched with the $\mathrm{t}$ table at significant level of 5\%. If it was known that $t_{\text {value }}$ is greater than $t_{\text {table, }}$, then there was a significant difference. The formula was:

$$
t=\frac{\bar{D}}{\left(\frac{S D}{\sqrt{N}}\right)}
$$

Description:

$D=$ the average margin of two scores

$S D=$ the standard deviation of the price D

$N=$ total pairs

Source: Danapriatna and Setiawan (2005: 108)

\section{RESULT AND DISCUSSION}

Focus of this research is in the development of Accounting Jenga, the feasibility of Accounting Jenga by experts and students' responses about Accounting Jenga, and measurement of students' motivation improvement.

\section{Result}

a. Analysis

Researcher conducted observation in class XI IPS 1 on July 19 2016. Based on the observation, 22 students from a total of 32 students or $69 \%$ of students do not pay attention to the teacher when the teacher is delivering the learning material. It shows that students who pay attention to the teacher's explanation only a small proportion. Thus, the researchers concluded that students' motivation in class XI IPS 1 is low.

Beside the low of students' motivation problem, researcher also faced with the problem of learning methods applied by teacher. Teacher never uses learning media every time 
the teacher teaches in the classroom. Teacher only uses textbook, explains the learning material by using speech method, and only use a whiteboard in the class to write down a few things that are important. It makes the learning activity becomes monotonous. In other words, there is nothing new in any learning activity that take place.

If it is done constantly, the students' motivation will be very difficult to be improved. If students have low motivation to learn, teacher will have difficulty to explain the learning material and students also will find difficulty to understand the teacher's explanation

Accounting subject itself is a subject with continuous material from the beginning to the end of learning activity. Therefore, researcher considered that the problem above should be resolved from the beginning of the accounting subjects presented in class XI IPS. So, the researcher considered that there is a need of learning media that can be applied in Basic Competence Understanding Accounting Equation.

By making Accounting Jenga hopefully can fulfill the students' need of learning media that can improve students' motivation. Besides that, the students' motivation can be improved by using this learning media.

b. Design

1) Make the design of the product

Accounting Jenga has a few differences with Jenga game in general. Accounting Jenga requires cards to deliver the learning material and also some questions which are accordance with the learning material. Therefore, the cards and all of the components of Accounting Jenga start to be designed in this stage. The cards are Material Cards, Bonus Cards,
Answer of Bonus Cards, Question Cards, Answer of Question Cards, Opportunity Cards, Challenge Cards (blue), Challenge Cards (black), and Point Cards.

Material Cards are used to deliver the learning material. The learning naterial that is written on this card will be delivered in simple language and also directly to the core of learning material. So, students can understand it easily. This card will also be equipped with animated picture that illustrates the learning material which is delivered, so it will look more interesting and can help the students to remember the learning material.

Question Cards contain questions related to the learning material which is presented on Material Card. Question Cards will be taken by the players when they acquire yellow color when rolling the dice. On each card there will be a point that is eligible to earn by the players when they can answer the question correctly. The point of Question Card is 2 for Level 1, 3 for Level 2, and 4 for Level 3.

Answer of Question Cards contain the answer of Question Cards. This card used to match the player's answer when they try to answer the question from Question Cards, so they can decide whether the answer is right or wrong.

Bonus Cards contain questions related to the learning material which is presented on Material Card. Bonus Cards will be taken by the players when they acquire white color when they roll the dice. On each card there will be a point that is eligible to earn by the players when they can answer the question correctly. The point of Question Card is 4 for Level 1, 6 for Level 2, and 8 for Level 3. 
Answer of Bonus Cards are cards that contain the answer to the question on Bonus Card. This card becomes the answer key that is used to match the player's answer to the question of Bonus Card. Then, they decide whether the answer is right or wrong.

Opportunity Cards used to give an opportunity for players to ask other players if there are any learning materials that they do not understand. This card will be drawn when the students get green color when rolling the dice. By creating this card, it is expected that students will talk to their group-mates, so each player will help each other to understand the learning material presented.

Challenge Cards contain challenges that will ask the players to take the Material Card, Question Card, Bonus Card, Opportunity Card, another Challenge Card, or remove certain blocks. Challenge Card will be made into two kinds, i.e. Blue and Black Challenge Cards.

Point Cards contain number of points for each Question Card and Bonus Card. This card will be taken after the player can answer the question from Question Card or Bonus Card correctly. This Point Card will be calculated at the end of the game to know the total point of each group.

The other components are inside box to contain jenga's blocks and the dice, outside box to contain all of the Accounting Jenga's components, card dividers to separate the cards into three levels, game instruction, and attachment of Material Cards Level 3.

2) Arrange the rule of the game

To be able to play, Accounting Jenga needs some instruction.
Therefore, researcher creates the game instruction in this stage.

3) Arrange the assessment instrument Instruments take form of questionnaires, i.e. validation questionnaire to validate the product which is developed, students' responses questionnaire to know the students' responses about Accounting Jenga, and students' motivation questionnaire to measure the students' learning motivation in class XI IPS 1. The items in students' motivation instrument are taken from indicators of learning motivation by Uno (2012: 23).

c. Development

1) Product making

Researcher starts to create the Accounting Jenga based on the result in the previous stage. Researcher creates the cards and any other things that are useful in this learning media by using Corel Draw X5. The design of the product is printed out in this stage.

2) Product validation by experts

Validation of Accounting Jenga is conducted by one lecturer material expert, one lecturer media expert, and one subject practitioner.

a) Material Expert

Material expert in this research is Mrs. Adeng Pustikaningsih, M.Si. Validation is done related to the feasibility of material aspect, language aspect, and learning aspect of Accounting Jenga that is developed by giving score 1-5 scale in the questionnaire.

b) Media Expert

Media expert in this research is Mr. Rizqi Ilyasa Aghni, M.Pd. Validation is done related to the feasibility of language aspect, visual display aspect and using technique of media aspect of 
Accounting Jenga that is developed by giving score 1-5 scale in the questionnaire.

c) Subject Practitioner

Subject practitioner in this research is Mrs. Suharti, S.Pd. who becomes the accounting teacher in SMA Negeri 1 Prambanan Klaten. Validation is done related to the feasibility of material aspect, language aspect, learning aspect, visual display aspect, and using technique of media aspect of Accounting Jenga that is developed by giving score 1-5 scale in the questionnaire.

3) Product revision stage I

Revision is done to minimise the mistakes and make Accounting Jenga feasible to be used as a learning media. Product Revision Stage I is conducted after the initial product is validated by material expert, media expert, and subject practitioner. Revision is done by following advices and suggestions from material expert, media expert, and subject practitioner.

d. Implementation

1) Small group tryout

Accounting Jenga has been tried out in a small group. The students who become the subject of this small group tryout are seven students in class XI IPS 3.

Small group tryout conducted twice. In first meeting, students are asked to learn by using Accounting Jenga Level 1. This meeting has been done on September 27 $7^{\text {th }}, 2016$.

In first meeting, the students are only asked to play Accounting Jenga Level 1 because there is a need of time to explain the game instruction. It is necessary to explain the game instruction in order to make the students understand the instruction well. Then, in second meeting, students are asked to play Accounting Jenga Level 2 and Level 3. This meeting has been done on October $1^{\text {st }}, 2016$.

2) Product revision stage II

Researcher does not conduct the product revision stage II because the conclusion based on the students' response in step small group tryout shows that Accounting Jenga is Strongly Feasible, students' comments relate to their subjective point of view, and time duration to play this game is suitable with the duration of learning activities in the classroom which for one meeting lasts for $2 \times 45$ minutes.

3) Field tryout

Accounting Jengs is implemented in field tryout. The students who become the subject of the field tryout are 29 students from class XI IPS 2. Those 29 students are grouped into four groups, namely Group 1, Group 2, Group 3, and Group 4. This class is chosen because the students have similar characteristic with students in XI IPS 1.

The field tryout conducted twice. The time allocation of each meeting is $2 \times 45$ minutes or 90 minutes. First meeting has been done on October $14^{\text {th }}, 2016$ and the second meeting has been done on October $18^{\text {th }}, 2016$.

In first meeting, the students are only asked to play Accounting Jenga Level 1. It is due to the necessity of time to explain the game instruction in order to make the students understand the instruction well. Then, the students are asked to play Accounting Jenga Level 2 and Level 3 in the second meeting.

4) Product revision stage III

This stage is done to make the time duration to play this game 
decrease and to give solution in the game instruction for players if a condition like Bonus Cards or Question Cards are already opened happens before the game ends.

Revisions are done by adding functions into Opportunity Cards that will direct the players to take Material Cards. Thus, the players' opportunity to take Material Cards will be increase.

The game instruction needs to be revised because there is an unpredictable condition happens in field tryout. This game ends when all of the Material Cards opened, but in field tryout all of the Bonus Cards are already opened before the game ends. Thus, game instruction has to be added based on the solution of this condition.

e. Evaluation

The final product of Accounting Jenga is obtained in this stage. The aim of developing Accounting Jenga is to improve students' motivation in class XI IPS 1 SMA Negeri 1 Prambanan Klaten. Therefore, the next step is implementing the final product in the learning process in class XI IPS 1 and measure the achievement of the product's objective.

\section{Discussion}

a. Development of Accounting Jenga

Development of Accounting Jenga has been done by following ADDIE Model by Dick and Carry (1996). ADDIE has function to be guidelines in creating a learning media that is effective, dynamic and supporting learning activities. This model uses five stages of development, namely Analysis, Design, Development, Implementation, and Evaluation. b. The feasibility of Accounting Jenga

Here is the feasibility score from material expert, media expert, and subject practitioner:

Table 4. Feasibility Score based on the Experts' Validation

\begin{tabular}{|l|c|c|}
\hline \multicolumn{1}{|c|}{ Expert } & $\begin{array}{c}\text { Total } \\
\text { Score }\end{array}$ & $\begin{array}{c}\text { Average } \\
\text { Score }\end{array}$ \\
\hline Material Expert & 97 & 4.83 \\
\hline Media Expert & 78 & 4.27 \\
\hline Subject Practitioner & 148 & 4.93 \\
\hline \multicolumn{2}{|r|}{ Total Average Score } & 4.74 \\
\hline
\end{tabular}

Based on the table above, it shows the feasibility of Accounting Jenga based on the validation from material expert obtained average score 4.83 and classified as Strongly Feasible, from media expert obtained average score 4.27 and classified as Strongly Feasible, and from subject practitioner obtained average score 4.93 and classified as Strongly Feasible.

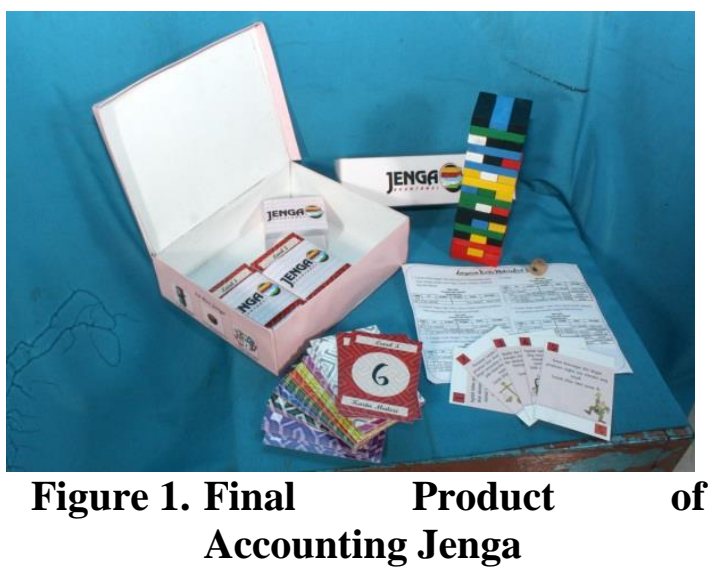

c. Students' responses about Accounting Jenga

When the product was implemented in small group tryout and field tryout, students were asked to fill out students' responses questionnaires to know their responses about Accounting Jenga as a learning media. Here is the students' responses score about Accounting Jenga: 
Table 5. Students' Responses Score about Accounting Jenga

\begin{tabular}{|l|c|c|}
\hline Students & $\begin{array}{c}\text { Total } \\
\text { Score }\end{array}$ & $\begin{array}{c}\text { Average } \\
\text { Score }\end{array}$ \\
\hline Small group tryout & 635 & 4.51 \\
\hline Field tryout & 2468 & 4.26 \\
\hline \multicolumn{2}{|r|}{ Total Average Score } & 4.39 \\
\hline
\end{tabular}

The table above shows that the average score from students in small group tryout is 4.51 and from students in field tryout is 4.26 . Both of them are classified as Strongly Feasible.

d. Students' motivation improvement

The final product of Accounting Jenga was implemented in class XI IPS 1 to improve the students' motivation. Students were asked to fill out the students' motivation instrument, before and after using Accounting Jenga as a learning media.

Data based on students' motivation questionnaire before and after using Accounting Jenga as a learning media is calculated. The result shows that students' motivation improves $6.62 \%$ from $73.02 \%$ to $79.32 \%$.

Then, the data is compared by using paired sample $t$ test. The result shows that sig $0.000<0.05$ and $\mathrm{t}$ value $5.287>\mathrm{t}$ table 2.0395. It means that the motivation improvement is significant.

\section{CONCLUSIONS AND SUGGESTIONS Conclusions}

Based on the research result and discussion, it can be concluded that:

a. Development of Accounting Jenga is conducted in five stages, i.e.: Analysis, Design, Development, Implementation, and Evaluation.

b. Accounting Jenga is Strongly Feasible based on the validation from experts. The average score based on the validation from material expert is 4.83 , the average score based on the validation from media expert is 4.27 , and the average score based on the validation from subject practitioner is 4.93.

c. Accounting Jenga is Strongly Feasible to be used. The average score from students' responses in small group tryout is 4.51 and the average score from students' responses in field tryout is 4.26 .

d. Students' motivation improves $6.62 \%$ from $73.02 \%$ to $79.32 \%$ and based on paired sample t test result shows that sig is $0.000<0.05$ and $t$ value $5.287>t$ table 2.0395. It means that the improvement is significant. Therefore, Accounting Jenga can improve students' motivation.

\section{Suggestions}

Based on the research result and the limitation of the study, Accounting Jenga still has weaknesses. Therefore, here are a few suggestions for a further research:

a. A further research is necessary to be done in order to decrease the time duration of the game.

b. Questions which are written on Bonus Cards and Question Cards should be validated first to know the quality.

c. A further research should pay attention to the learning material that will be delivered by using Accounting Jenga because the appropriate learning material is theoretical material or simple calculation material which have narrow scope of it.

\section{REFERENCES}

Ali, Mohammad. (2010). Metodologi dan Aplikasi Riset Pendidikan. Bandung: Pustaka Cendekia Utama.

Danapriatna, Nana and Rony Setiawan. (2005). Pengantar Statistika. Yogyakarta: Graha Ilmu.

Hidayat, Restu Resmiadi. (2013). Digital Library Perpustakaan Pusat UNIKOM: Membangung Game Side Scrolling 2D Petualangan Kabayan Menyelamatkan Makanan Tradisional. Accessed on March 15 , 2016 from: 
http://elib.unikom. ac.id/files/disk1/622/jbptunikomppgdl-resturesmi-31065-10-unikom _r2.pdf

Kholidiyah, Ulfi. (2013). "Hubungan antara Intensitas Bermain Game Online dengan Kecerdasan Emosi". Naskah Publikasi. Accessed on March 23 ${ }^{\text {rd }}, \quad 2016$ from: http:// eprints.ums.ac.id/27192/24/02. Naska h_Publikasi_- Ulfi_Kholidiyah.pdf

Mulyatiningsih, Endang. (2011). UNY Staff Site: Pengembangan Model Pembelajaran. Accessed on October $12^{\text {th }}, 2015$ from: http://www.staff. uny.ac.id/sites/default/files/pengabdia n/dra-endang-mulyatiningsih-mpd/ 7cpengembangan-model-pembelajar an.pdf

Muruganantham, G. (2015). "Developing of E-Content Package by Using ADDIE Model". International Journal of Applied Research Volume 1 (Issue 3 Page 52-54). Accessed on December $8^{\text {th }}, \quad 2015$ from: http:// www.allresearchjournal.com/archives/ 2015/vollissue3/ PartB/67.1.pdf

Pinasthika, Lalitya Talitha, Deddy Wahjudi, Ruly Darmawan. (2014). Jurnal Sosioteknologi volume 13 nomor 3: Permainan Jenga (Digital dan Analog) pada Anak Usia Prasekolah. Bandung: ITB Publisher.

Setyosari, Punaji. (2012). Metode Penelitian Pendidikan dan Pengembangan. Jakarta: Kencana.

Siswoyo, Dwi. (2013). Ilmu Pendidikan. Yogyakarta: UNY Press.

Sugar, Steve dan Kim Kostoroski Sugar. (2002). Primary Games: Experiental Learning Activities for Teaching Children K-8. San Fransisco: JosseyBass.

Sugiyono. (2012). Metode Penelitian Kuantitatif Kualitatif dan $R \& D$. Bandung: Alfabeta.

Sukardjo. (2005). Evaluasi Pembelajaran Semester 2. Yogyakarta: PPs UNY.
Tim Dosen UPI. (2012). Manajemen Pendidikan. Bandung: Alfabeta.

Uno, Hamzah B. (2012). Teori Motivasi dan Pengukurannya. Jakarta: Bumi Aksara.

Widoyoko, Eko Putro. (2011). Evaluasi Program Pembelajaran. Yogyakarta: Pustaka Belajar.

Williamson, Ben. (2008). Future Lab: Games and Learning Interim Report Survey of Existing Research and Criticism. Accessed on October $21^{\text {st }}$, 2015 from: http://www2.futurelab. org.uk/resources/documents/project_re ports/Games_learning_review.pdf 